\title{
The Role of Public Policy in Emerging Green Power Markets: An Analysis of Marketer Preferences
}

\author{
Ryan H. Wiser \\ Environmental Energy Technologies Division \\ Ernest Orlando Lawrence Berkeley National Laboratory \\ University of California \\ Berkeley, California 94720
}

August 1999

The work described in this study was funded by the Assistant Secretary of Energy Efficiency and Renewable Energy, Office of Power Technologies of the U.S. Department of Energy under Contract No. DE-AC03-76SF00098. 


\section{Table of Contents}

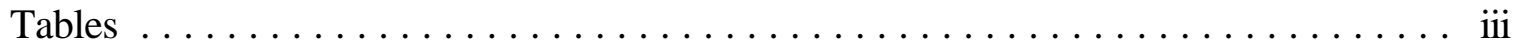

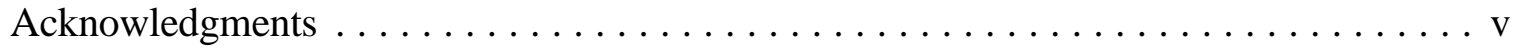

Abstract ..............................

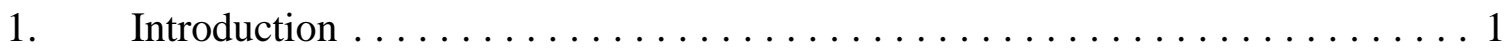

$1.1 \quad$ Research Objectives and Definition . . . . . . . . . . . . . 1

2. Theoretical Underpinnings and Literature Review $\ldots \ldots \ldots \ldots \ldots \ldots$

2.1 The Economics of Markets and Market Intervention . . . . . . . . . . 5

2.2 Previous Research and Policy Debates .............. 7

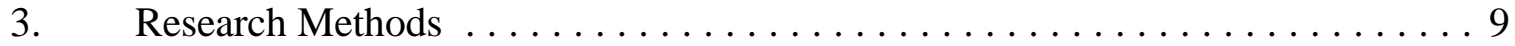

3.1 Data Sources and Survey Design $\ldots \ldots \ldots \ldots \ldots \ldots$

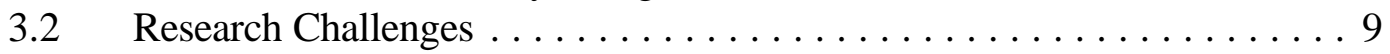

4. Market Barriers to the Development of Green Power Markets . . . . . . . 11

5. Rules and Facilitation Efforts to Overcome Market Barriers . . . . . . . . 13

5.1 Competitive Market Rules . . . . . . . . . . . . . . . . . . . . 13

5.2 Green Power Market Facilitation Efforts . . . . . . . . . . . . . 21

6. Key Research Findings . . . . . . . . . . . . . . . . . . . . . 29

7. Implications, Tension, and Unanswered Questions $\ldots \ldots \ldots \ldots \ldots \ldots$

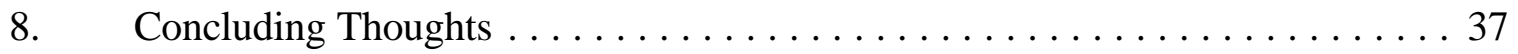

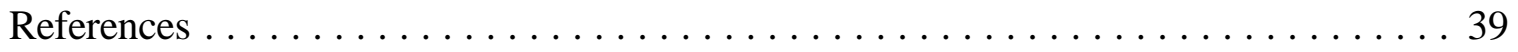




\section{List of Tables}

Table 1. Market Barriers to the Development of the Green Power Market:

Survey Results . . . . . . . . . . . . . . . . . . . 12

Table 2. Relative Ranking of Market Rules: Survey Results . . . . . . . . 14

Table 3. Relative Ranking of Market Facilitation Efforts: Survey Results . . . . . 22 


\section{Acknowledgments}

Work reported here was funded by the Assistant Secretary for Energy Efficiency and Renewable Energy, Office of Power Technologies of the U.S. Department of Energy (DOE). I would particularly like to thank the numerous green marketers who contributed to this work. I also appreciate the support of my DOE and LBNL colleagues, specifically Jack Cadogan, Diane Pirkey, Joe Galdo, Joe Eto, Chuck Goldman, and Bill Golove. The guidance and comments of Richard Norgaard, Lee Friedman, and Christine Rosen, all of U.C. Berkeley, have also been indispensable. 


\section{Abstract}

Green power marketing has been heralded by some as a means to create a private market for renewable energy that is driven by customer demand for green products. This report challenges the premise-sometimes proffered in debates over green markets-that profitable, sizable, credible markets for green products will evolve naturally without supportive public policies. Relying primarily on surveys and interviews of U.S. green power marketers, the article examines the role of specific regulatory and legislative policies in "enabling"the green market, and searches for those policies that are believed by marketers to be the most conducive or detrimental to the expansion of the green market.

We find that marketers: (1) believe that profitable green power markets will only develop if a solid foundation of supportive policies exists; (2) believe that establishing overall price competition and encouraging customer switching are the top priorities; (3) are somewhat leery of government-sponsored or mandated public information programs; and (4) oppose three specific renewable energy policies that are frequently advocated by renewable energy enthusiasts, but that may have negative impacts on the green marketers' profitability.

The stated preferences of green marketers shed light on ways to foster renewables by means of the green market. Because the interests of marketers do not coincide perfectly with those of society, however, the study also recognizes other normative perspectives and highlights policy tensions at the heart of current debates related to green markets. By examining these conflicts, we identify three key policy questions that should direct future research: To what extent should price competition and customer switching be encouraged at the expense of cost shifting? What requirements should be imposed to ensure credibility in green products and marketing? How should the green power market and broader renewable energy policies interact? 


\section{Introduction}

This article examines the role of public policy in developing markets for renewable energy by facilitating transactions between "green power" sellers and buyers. There is concern in some quarters that renewables (primarily solar, wind, geothermal, and biomass) will fare poorly if traditional policy measures designed to support these technologies are abandoned as electricity restructuring is introduced. To capture the social benefits that renewables can provide, some therefore advocate continuation of policy incentives targeted at renewable generators [1]. At the same time, restructuring and the advent of retail competition are also increasing product differentiation as power marketers compete for customers. Green power marketing-selling electricity products based on their environmental attributes-has emerged as a way for marketers to attract customers [2]. It has been heralded by some as a means to create a new, sizable, self-sustaining market for renewables that is insulated from the cycle of "on-again, off-again" renewable energy policies [3]. Consequently, some research and advocacy attention has shifted away from traditional policy approaches and toward the green market.

Experience in both regulated and deregulated contexts provides empirical evidence that a niche market for "green power" exists among electric customers. For example, about 40 U.S. utilities have launched regulated green power programs that allow customers to support renewables through price premiums or donations; up to $5 \%$ of residential customers participate [4]. More importantly, recent experience with retail competition in the U.S. confirms that some power marketers will offer green products in a competitive context, with similar short-term customer response [5]. Finally, green marketing is not solely a U.S. endeavor, with growing activity throughout the world [6].

Despite the increase in green offerings, however, green power demand in most jurisdictions has been far lower than surveys would seem to suggest [7]; demand has typically ranged from $1-3 \%$ of residential customers. Further, the truthfulness of the "green" claims and the environmental quality of the "green" products have frequently been questioned. An active debate therefore remains over whether green marketing can ever create a "significant" market for renewable energy. There are, it seems, a number of challenges to the emergence of a sizable, credible green market. One class of potential obstacles derives from the regulatory and legislative policies being established as part of electricity market reform. These policies address details ranging from stranded cost recovery and unbundling to disclosure requirements and "green power" definitions.

\subsection{Research Objectives and Definition}

There is a growing consensus that regulatory and legislative policies will play a decisive role in both shaping the competitive electricity market broadly [8], and in influencing the size and credibility of the green power market specifically [9]. Some U.S. states have even expressed an interest in designing policies to specifically promote-or to at least not stifle-the green market. However, little research has been done to systematically identify, review, or prioritize 
the policy decisions that might affect the green market. This article begins to fill this research void and, in so doing, seeks to provide insights about ways to foster renewables through the green market. We focus on the following key research questions:

- What regulatory "market barriers" impede development of the green market?

- What role might public policy play in breaking down these barriers? What is the relative importance of specific "market rules" and "market facilitation efforts" in promoting renewable energy use via the green power market? Could some seemingly unobjectionable policy decisions unintentionally stifle the development of the green market?

- What are some of the important policy tradeoffs facing regulators and legislators?

Market barriers are defined here as regulatory or market conditions that might restrict the size and/or credibility of the green market. Competitive market rules are defined as the basic structural and operational rules established by regulators and legislators as part of electricity reform that will affect all suppliers of electricity (e.g., rules related to stranded cost recovery, direct access process and timing, customer education, market power, etc.). Green power market facilitation efforts are defined as programs and policies that directly and differentially impact green power providers relative to other electricity suppliers and that may be intended to directly promote the market for green power sales (e.g., environmental disclosure, renewable energy subsidies, green power definitions, etc.). Both market rules and facilitation efforts are forms of public policy, and both may either reduce or enhance market barriers. We distinguish between these two broad forms of policy because, as we will show, green power marketers believe that the competitive market rules should be given higher priority by policymakers than the more directed forms of green power facilitation.

For purposes of this study, we assume that increasing the use of renewable energy is a desirable social objective and that green marketing may be a legitimate (though not the only) way to proceed toward that objective. We do not tackle the question of whether there is adequate justification for supporting renewables, nor do we debate the merits of green marketing as an appropriate tool for developing renewables. Instead, we contribute to the emerging green marketing literature by addressing the questions raised above from the unique perspective of those companies attempting to build and profit from this market-the green power marketers. We rely on marketer surveys and interviews as our primary sources of data because we believe that the views of those most directly affected by policy decisions offer a useful perspective from which to evaluate the impact of those decisions on the market for green power. We also echo Knight's [10] concern that the focus of restructuring has been "utility-centric" and that increased attention to the perspectives of competitive marketers is warranted. Where possible, we compare and contrast the preferences of marketers with those of the academic literature and conventional wisdom. Because the interests of marketers do not necessarily coincide with those of society, we also account for other normative perspectives and highlight key policy tensions among different interest groups. An understanding of the nature and scope of these tensions can help advocates and policymakers make decisions about programs to support renewable energy and the green market. Future 
work should explore the interests of other stakeholders in more detail in order to better characterize these tensions.

We begin this article in Section 2 with a discussion of the theoretical underpinnings of our work and a brief literature review. Section 3 then describe our research methods. Based on the results of the marketer surveys and interviews, we identify and prioritize various market barriers, rules, and facilitation efforts in Sections 4 and 5. Aspects of current regulatory policies in specific U.S. states are used to selectively illustrate the policy design issues raised. Four general research findings that emerge from the detailed survey results are then summarized in Section 6. Finally, in Section 7, research and policy implications are described, highlighting areas of tension between the perspectives of marketers and those held by other interest groups. 


\section{Theoretical Underpinnings and Literature Review}

In the abstract, retail competition and customer choice implies relying on the market rather than on regulation to establish the rates, terms, and conditions of electricity service. Nonetheless, most would acknowledge that some form of government intervention is needed to ensure that efficient market outcomes are achieved and that these outcomes are consistent with broad social interests. The economics literature, in particular, helps us understand the role that government regulation plays in creating and shaping markets. Below, we highlight important themes of the economics literature in this area and briefly review related research efforts on electricity industry policy. The conclusions reached here provide the theoretical basis for the current study.

\subsection{The Economics of Markets and Market Intervention}

Three important lessons for the research presented in this article can be extracted from the economic literature on markets and market intervention.

First, to create a competitive electricity market where one has not historically existed and to ensure that the market operates consistent with the public interest, it is not enough to simply mandate customer choice and call the market "open." Instead, though conceptions of "the market" have historically varied across disciplines [11][12], there is wide acknowledgment that some form of government intervention is an inescapable element of all markets. After all, though capitalist societies emphasize private exchange as the primary method of resource allocation, markets cannot generally be found in a "state of nature"[13]. Instead, the economics literature shows that all markets exist within an institutional [14][15] and social [16][17] environment and are defined in part by the government rules under which they operate [18][19][20]. As noted by Harris \& Carman [21], these rules unavoidably shape the outcomes of market transactions. The relevant question then becomes not whether there should or should not be government intervention, but rather what the nature and scope of that intervention should be. Consequently, because the electricity industry has traditionally been governed by economic regulation, the structure and operations of the new competitive market will need to be defined and interactions between regulated and unregulated industry segments stipulated. These policy decisions will clearly help shape the competition that emerges.

Second, the range of policy instruments available to encourage the green market need not be limited to extremes of Soviet-style central planning versus unfettered free choice. Rather, a wide variety of policy options exist and attention must be directed to how alternative policies will work in practice rather than to hypothetical ideals. While the traditional "market failures" framework of neoclassical economics provides only limited guidance to policymakers on when and how governments should intervene in markets, the institutional and transaction-cost economics literature provides more useful general guidance. A brief digression into market failures and transaction cost economics will help explain these conclusions. 
Market failures provide the most common rationale for government intervention in markets according to neoclassical economics, and many of the competitive market rules and green power facilitation efforts identified in this article can be seen as ways to combat potential market failures. A market failure exists when any of a number of conditions exist: few buyers and sellers, significant barriers to entry or exit, externalities or public goods, and costly and imperfect information [22] [23]. Market failures are common--pervasive, even--in the real world, however, and the institutions that seek to correct them are neither perfect nor costless themselves [24]. Moreover, there is no one-to-one correspondence between the type and magnitude of a market failure and the appropriate policy response. Finally, the market failures framework is fundamentally static, emphasizing equilibrium states in mature markets rather than dynamic adjustment processes in emerging markets [25] [26]. Consequently, this framework provides only weak guidance regarding the infinite range of policy choices that may be usefully employed in emerging markets [27].

Most importantly, analysis of market failures often centers on a false dichotomy between reliance on "markets" and reliance on "government"[28]. For example, the strictest version of the public-goods, free-rider theory suggests that the private provision of public goods is untenable and that consumers are generally unwilling to pay extra for products that provide environmental benefits to society as a whole. Therefore, if the public good is to be provided, a strong government role is required. Yet, this rendering of the situation is oversimplified. Although we need to recognize the real limits of markets when public goods are involved, a great deal of theoretical, experimental and empirical work shows that individual consumers are sometimes able to provide public goods to some extent [29][30]. Ostrom [31] therefore notes that policies designed based on the assumption that people are unable to privately provide public goods may be less successful than those that recognize the possible marriage between markets and policies. From this perspective, a whole range of policy instruments that might enhance the opportunities for the private provision of public goods can be considered; these policies are neglected under the traditional public goods theory.

Institutional and transaction-cost economics provides a better theoretical framework for understanding the range of institutional choices that exist in the continuum between "free markets" and "strict government regulation." As noted by Arrow [32], "market failure is not absolute, it is better to consider a broader category, that of transaction costs, which in general impede and in particular cases absolutely block the formation of markets." Transaction-cost economics, in contrast to neoclassical economics, recognizes that market transactions almost always have costs and that these costs depend on the manner in which the transactions are institutionally configured. By incorporating transaction costs, this literature does away with the neoclassical economic goal of creating a "perfectly" competitive market and an "optimally" efficient economy. The transaction-cost perspective therefore allows us to consider a wider range of policy options than are available from the perspective of market failures and "first-best" policies [33]. The transaction-cost viewpoint also directs attention to how alternative policies actually work in practice, while the market failures analyst often disdains these real-world particulars [34][35]. Within this framework, and as recognized by Coase's [36] seminal work, the goal of government is, in part, to configure market institutions to minimize transaction costs consistent with overall social objectives. 
Third, and finally, we also find that economic theory provides only limited guidance about how to create specific markets where they have not historically existed and about how to design and implement effective policy measures. There is, after all, a tendency for academic models to rely on theoretical constructs and to thereby oversimplify policy reform challenges [37][38]. As a result, using theory as our only guide, the relationships between the design of the electricity market and the shape and performance of that market are not entirely obvious a priori. Even if one is convinced that encouraging green power is a justifiable objective, economic theory provides only limited guidance on which policy approaches would best serve that objective.

\subsection{Previous Research and Policy Debates}

A growing and more topical literature among energy specialists has begun to explore the role and importance of policy in the competitive electricity market in ways that economic theory cannot. Yet, while this literature is beginning to explore policy nuances in more detail, it too has some serious shortcomings. Specifically, it has not focused on issues related to retail market design. Most academic attention has instead concentrated on increasing competition in electricity generation and on wholesale market design issues, including market power, market structure, reliability services, and transmission pricing. Stranded assets have also received significant coverage. Although regulators have begun to consider issues related to retail market design, including pricing default utility service, customer education, directaccess phase-ins and processing, unbundling of revenue-cycle services, and customer aggregation, little academic literature exists on these subjects.

With respect to green power specifically, many current debates embrace what we believe is a false dichotomy between "market" and "governmental" approaches to increasing the use of renewable energy, a descendent of "market failures" thinking, discussed earlier. One side claims that, with the development of green markets, strong policy supports will no longer be required; the other emphasizes the fundamental limits to green consumerism and advocates the continuation of traditional policies directed at renewable generators. Although this debate is useful for questioning the role that green marketing might play in supporting renewables in contrast to more directed forms of policy, it has taken attention away from the role of policy in the formation of the green market itself. Where this role has been addressed, emphasis has been on market facilitation efforts that directly shape and promote the green market, including disclosure regulations, green power definitions, and renewables subsidies [39]. With a few exceptions [40], the design of detailed, fundamental competitive market rules has not been emphasized. 


\section{Research Methods}

\subsection{Data Sources and Survey Design}

To begin to fill the void in the existing literature and to evaluate the role of policy in the green market, this article presents data gathered from one important set of market participants, green marketers. Most of our data come from a mail survey of U.S. green power marketers. Additional information comes from informal interviews with several green marketers, used to probe in more detail specific marketer responses to the survey questions. We also obtained background information on competitive market rules and green power facilitation efforts by reviewing the regulatory filings of power marketers and other stakeholders (renewable generators, policymakers, environmental advocates, etc.). Our research method is, to some extent, modeled after that of Karakaya and Stahl [41], who survey business executives to assess the relative importance of "entry barriers" in a number of industries.

Our survey was designed to elicit information on the relative importance of different types of market barriers, market rules, and market facilitation efforts for the green power market. In order to craft the survey instrument, we created a typology of possible market barriers, rules, and facilitation efforts. To create this typology, we reviewed regulatory filings, academic literature and gray literature, and we pre-interviewed a limited set of marketers. Fifteen potential market barriers and 47 market rules and market facilitation efforts were ultimately identified. The survey itself was mailed to a census of all 15 known U.S. green power marketers operating in competitive electricity markets that had sold, were selling, or had announced plans to sell power products differentiated based on the environmental characteristics of the power supply. Both open- and closed-ended questions were included. To increase response rates and improve the prospects for unbiased responses, we indicated that the responses of individual marketers would not be identified.

Ultimately, 12 of 15 questionnaires were returned. Not all marketers responded to each question, so response rates to individual questions vary. The 12 marketers who responded to the survey can be classified based on a number of different characteristics. In the near term, most have sold or intend to sell green power in California, the Northeast, or both regions. Four marketers are retailers of green power, three are wholesalers, and five are both wholesalers and retailers. Seven of the 12 marketers are affiliated with an electric utility. Four of the marketers have sold or will only sell green electricity products; eight have or expect to have a product line that includes nongreen products as well.

\subsection{Research Challenges}

As with all research, there are of course limitations to our research methods and design. Perhaps most importantly, because the objective of this research is to explore key electricity market design issues from the point of view of one critical category of stakeholders, a fundamental challenge arises when attempting to draw broad policy implications from our data. After all, most stakeholders are driven by their own narrow interests, and firms 
frequently use government intervention to handicap their competition [42]. This research therefore does not attempt to make strong recommendations on the "ideal" set of policies needed to develop the green power market. Instead, our goal is to report the interests of green power marketers, draw some implications from the results on the relative value of different forms of policy, and identify areas where the interests of marketers and various other stakeholder groups may not coincide.

Even with these important but restricted objectives, however, three additional research-design challenges, and how we chose to manage them, are highlighted here. Most of these challenges reflect the difficulty in generalizing the results of the survey into an unbiased assessment of what is in the best interest of all green marketers.

First, because electric markets are only now beginning to open, and California and Northeastern U.S. are moving more rapidly than other regions, the marketers surveyed in this research are limited in number (only 12) and survey responses are likely to be somewhat biased by regional concerns. Despite these drawbacks, we chose to proceed with the research design because of the speed of the restructuring process in the U.S. and worldwide, and the resultant near-term need for information on the role of policy in the formation of the green market. Nonetheless, our results should be viewed with some caution. Because the size of the survey population is small, our goal was not to develop statistically significant descriptive statistics but to discern general trends.

Second, marketers are not a homogenous group; they differ based on the market niche they serve, their organizational structure, and the "greenness" of their product offerings. This makes a general interpretation of the survey results at times difficult. Similarly, though surveys were sent to individuals involved with the green power business, some responses came from individuals who clearly held corporate positions that were not just specific to their green product line; these responses may therefore reflect the corporation's overall strategic goals, not just those related to green power. To clarify differences among respondents, we specifically highlight areas where different perspectives appear to systematically affect the survey results.

Third, the survey population is limited to marketers that have decided to sell green power. We are therefore only reaching players who have chosen to enter the market as it is currently structured and regulated. We address this limitation at least partially by including marketers that operate in different parts of the country, each of which has its own set of regulatory policies. Nonetheless, because it is impractical to survey companies that might have entered the green market had it been structured differently, we can only acknowledge this limitation. 


\section{Market Barriers to the Development of Green Power Markets}

In this and the subsequent section we present detailed research results, principally from marketer surveys and interviews. This section begins by briefly reviewing survey responses that prioritize possible "market barriers." Using these responses to structure our subsequent discussion, we present survey and interview results in more detail in Section 5, describing the marketers' views on how to best overcome market barriers through the design of competitive market rules and green power facilitation efforts.

In order to determine the relative importance of the 15 market barriers that we identified as potentially thwarting the development of the green power market, each marketer was asked to review the list of 15 barriers and specify the five that they consider to be the "most serious" in terms of its potentially negative impact on the green marketer's business. Table 1 presents the aggregated results of this survey question. Barriers listed near the top of table were deemed "more serious" by the largest number of marketers; they include the low cost of utility default service, lack of renewable energy supply, onerous direct access processing and service fees, protracted direct access phase-ins, lack of customer education on retail choice, and stranded cost recovery. Less serious barriers include lack of sufficient customer protection regulations and barriers to consumer aggregation.

To structure the following discussion, we separate the 15 market barriers into two categories: (1) barriers that we believe specifically relate to the green market (and that can therefore be targeted with green power facilitation efforts), and (2) barriers that seem to affect the entire competitive electric market (and that can therefore be targeted with competitive market rules). The former are shaded in Table 1; the latter are unshaded. 
Table 1. Market Barriers to the Development of the Green Power Market: Survey Results

\begin{tabular}{|l|l|}
\hline Market Barrier & $\begin{array}{c}\text { Number of Times } \\
\text { Identified as } \\
\text { "Most Serious" }\end{array}$ \\
\hline Low cost of utility default service & 7 \\
$\begin{array}{l}\text { Lack of existing renewable energy plants that are able to sell to marketers due to } \\
\text { contract restrictions }\end{array}$ & 7 \\
$\begin{array}{l}\text { Direct access processing and service fees that erect barriers for new participants } \\
\text { (via high costs, slowness, lack of parity between marketers and utilities, etc.) }\end{array}$ & 6 \\
Protracted direct access phase-ins that favor larger customers & 6 \\
Lack of customer education on retail choice+ & 6 \\
Stranded cost recovery & 6 \\
Lack of customer education on renewable energy & 5 \\
Market power of electric utilities and their affiliates & 4 \\
$\begin{array}{l}\text { Transmission pricing, ancillary services, and bidding rules that penalize } \\
\text { intermittent, low capacity factor, distant renewable generators }\end{array}$ & 3 \\
Insufficient unbundling of revenue-cycle services (metering, billing, etc.) & 2 \\
No mandatory fuel source and/or emissions disclosure & 2 \\
Power pooling structures that do not allow direct bilateral contracts (but do allow & 2 \\
contracts-for-differences and other financial contracts) & 2 \\
Insufficient definition(s) of green power & 1 \\
Lack of sufficient customer protection regulations & 0 \\
Barriers to aggregation of electricity consumers based on geography or affinity & \\
\hline
\end{tabular}

** Shaded rows indicate barriers that specifically relate to the green market (and that can therefore be targeted with "facilitation efforts") whereas unshaded barriers are those that impact the competitive market more broadly (and that can therefore be targeted with "market rules"). 


\section{Rules and Facilitation Efforts to Overcome Market Barriers}

Given the existence of market barriers to the development of the green power market, as identified above, what do marketers believe can be done to remove them or at least minimize their impact? By definition, market rules and market facilitation efforts are forms of public policy that can either reduce or enhance these barriers. A key goal of the marketer survey was therefore to map the general market barrier concerns discussed above into specific recommendations on how to structure competitive market rules and green power facilitation efforts.

Section 5.1 reports on the survey and interview questions that emphasized competitive market rules and that therefore target the unshaded market barriers listed in Table 1. Section 5.2 reports on questions that focused on green power facilitation efforts, and that relate to the shaded market barriers. Both sections are structured around the barriers listed in Table 1, though Section 5.2 also discusses a number of renewable energy and green power policies that do not directly target any of the market barriers but that might affect the green market. For each market barrier and associated rules or facilitation efforts, we supply a brief review of the regulatory issue, report the results from the survey and interviews, and where appropriate provide some interpretation of the results.

\subsection{Competitive Market Rules}

Table 2 provides a list of market rules that seem likely to impact all electricity marketers. The rules are divided into groups that relate to the market barriers discussed above. As part of state and federal restructuring proceedings, the design of these detailed rules is being established. Green power marketers in our survey were asked to rate each rule on a 5-point importance scale, where 1 means that the marketer believes that the rule is "valuable" for their business (but far from essential) and 5 means that the marketer believes that the rule is "essential" for their business. Respondents could also indicate opposition to a rule. ${ }^{1}$ Table 2 shows the frequency distribution of the results. Several open-ended questions were used to probe for details regarding marketers' attitudes toward specific market rules. We begin our discussion of these results by focusing on the market barriers (and the associated market rules) ranked as "most serious" by the largest number of marketers: default service pricing, customer education, protracted direct access phase-ins, direct access processing, and stranded assets. We then cover barriers and rules regarded by marketers as less important: market power, unbundling, power pooling, customer protection, and customer aggregation.

1 Note that the scale used is not a standard 5, 7, or 10-point Likert-type scale for measuring opinion. We chose the 5-point positive importance scale, with the single option for opposition, because we were largely attempting to distinguish among positive ratings of different possible policies-we were not attempting to distinguish among the strength of opposition towards a policy. 
Table 2. Relative Ranking of Market Rules: Survey Results

\begin{tabular}{|c|c|c|c|c|c|c|}
\hline Market Rules Affecting all Marketers & $\begin{array}{l}\text { My } \\
\text { company } \\
\text { opposes } \\
\text { this rule }\end{array}$ & $\begin{array}{l}\text { My company } \\
\text { believes this } \\
\text { rule is } \\
\text { "valuable" } \\
+1\end{array}$ & +2 & +3 & +4 & $\begin{array}{l}\text { My company } \\
\text { believes this } \\
\text { rule is } \\
\text { "essential" } \\
+5\end{array}$ \\
\hline \multicolumn{7}{|l|}{ LOW COST OF UTILITY DEFAULT SERVICE } \\
\hline $\begin{array}{l}\text { Establish default utility service rates that provide } \\
\text { sufficient margin to encourage entry of competitive } \\
\text { suppliers }\end{array}$ & 0 & 0 & 0 & 2 & 3 & 5 \\
\hline \multicolumn{7}{|c|}{$\begin{array}{l}\text { DIRECT ACCESS PROCESSING AND SERVICE FEES THAT ERECT BARRIERS FOR NEW } \\
\text { PARTICIPANTS }\end{array}$} \\
\hline $\begin{array}{l}\text { Minimize charges for noncompetitive services } \\
\text { imposed by electric utilities on marketers (e.g., } \\
\text { costs for customer switching) }\end{array}$ & 0 & 0 & 0 & 0 & 2 & 8 \\
\hline $\begin{array}{l}\text { Allow use of load profiles for smaller residential and } \\
\text { commercial customers }\end{array}$ & 1 & 1 & 0 & 0 & 2 & 6 \\
\hline $\begin{array}{l}\text { Uniformity and consistency across utility service } \\
\text { territories for data transfer protocols, direct access } \\
\text { service tariffs and agreements, metering and billing } \\
\text { requirements, and other rules }\end{array}$ & 0 & 0 & 1 & 2 & 4 & 3 \\
\hline $\begin{array}{l}\text { Parity between marketers and utilities with respect } \\
\text { to obligations, rights, and charges for billing, } \\
\text { metering, data transfer, service agreements, } \\
\text { avoided cost credits, customer contracts, etc. }\end{array}$ & 0 & 1 & 1 & 1 & 1 & 5 \\
\hline $\begin{array}{l}\text { Require utilities to rapidly process direct access } \\
\text { service requests }\end{array}$ & 1 & 1 & 1 & 2 & 1 & 4 \\
\hline \multicolumn{7}{|c|}{ PROTRACTED DIRECT ACCESS PHASE-INS THAT FAVOR LARGER CUSTOMERS } \\
\hline $\begin{array}{l}\text { If a direct access phase-in exists, allow residential } \\
\text { customers to receive choice on the same schedule } \\
\text { as other customer classes }\end{array}$ & 0 & 4 & 0 & 1 & 2 & 3 \\
\hline $\begin{array}{l}\text { Full direct access on a date certain without direct } \\
\text { access phase-ins }\end{array}$ & 1 & 1 & 2 & 3 & 1 & 2 \\
\hline \multicolumn{7}{|c|}{ LACK OF CUSTOMER EDUCATION ON RETAIL CHOICE } \\
\hline $\begin{array}{l}\text { Funding for broad-based, nondiscriminatory } \\
\text { customer education on retail choice }\end{array}$ & 0 & 3 & 1 & 1 & 1 & 4 \\
\hline \multicolumn{7}{|l|}{ STRANDED COST RECOVERY } \\
\hline $\begin{array}{l}\text { Establish incentives for stranded cost mitigation by } \\
\text { electric utilities }\end{array}$ & 0 & 1 & 0 & 1 & 5 & 3 \\
\hline $\begin{array}{l}\text { Recover stranded costs via a stable cents/kWh } \\
\text { charge, not a charge that depends inversely on the } \\
\text { power exchange clearing price }\end{array}$ & 1 & 2 & 0 & 1 & 3 & 1 \\
\hline $\begin{array}{l}\text { Require stranded costs to be recovered in a short } \\
\text { period of time }\end{array}$ & 1 & 2 & 0 & 3 & 1 & 2 \\
\hline Less than $100 \%$ recovery of stranded costs & 4 & 1 & 1 & 0 & 2 & 2 \\
\hline
\end{tabular}




\begin{tabular}{|c|c|c|c|c|c|c|}
\hline \multicolumn{7}{|c|}{ MARKET POWER OF ELECTRIC UTILITIES AND THEIR AFFILIATES } \\
\hline Creation of an independent system operator & 0 & 0 & 1 & 1 & 5 & 3 \\
\hline Utility divestiture of generation assets & 1 & 0 & 0 & 2 & 3 & 3 \\
\hline $\begin{array}{l}\text { Restrictions on utility affiliate marketing in their } \\
\text { parent utility service territory and/or their use of the } \\
\text { utility name and logo }\end{array}$ & 5 & 1 & 0 & 0 & 0 & 4 \\
\hline $\begin{array}{l}\text { Regulations that require sharing of customers that } \\
\text { choose not to switch suppliers (i.e., creation of } \\
\text { multiple default service providers) }\end{array}$ & 3 & 2 & 1 & 1 & 2 & 1 \\
\hline \multicolumn{7}{|c|}{ INSUFFICIENT UNBUNDLING OF REVENUE-CYCLE SERVICES } \\
\hline Full and fair unbundling of billing services & 0 & 2 & 1 & 2 & 1 & 4 \\
\hline Full and fair unbundling of metering services & 0 & 2 & 2 & 2 & 2 & 1 \\
\hline \multicolumn{7}{|c|}{ POWER POOLING STRUCTURES THAT DO NOT ALLOW DIRECT BILATERAL CONTRACTS } \\
\hline $\begin{array}{l}\text { Bilateral trading market structure as opposed to a } \\
\text { pooling structure }\end{array}$ & 0 & 2 & 0 & 3 & 3 & 3 \\
\hline \multicolumn{7}{|c|}{ LACK OF SUFFICIENT CUSTOMER PROTECTION REGULATIONS } \\
\hline $\begin{array}{l}\text { Establish marketer credit requirements during } \\
\text { marketer registration process }\end{array}$ & 1 & 4 & 2 & 3 & 1 & 0 \\
\hline $\begin{array}{l}\text { Establish a code of conduct for all marketers during } \\
\text { marketer registration process at PUC }\end{array}$ & 2 & 1 & 1 & 2 & 3 & 1 \\
\hline $\begin{array}{l}\text { Independent verification of customer orders to } \\
\text { switch electric providers }\end{array}$ & 1 & 5 & 1 & 1 & 2 & 0 \\
\hline \multicolumn{7}{|c|}{ BARRIERS TO AGGREGATION OF ELECTRICITY CONSUMERS } \\
\hline $\begin{array}{l}\text { Removal of barriers to geography and affinity- } \\
\text { based aggregation of customers }\end{array}$ & 0 & 5 & 1 & 2 & 1 & 1 \\
\hline $\begin{array}{l}\text { Allow local governments to act as default service } \\
\text { providers without a positive declaration by each } \\
\text { customer (customers could opt out) }\end{array}$ & 7 & 2 & 1 & 1 & 0 & 0 \\
\hline
\end{tabular}

Low Cost of Utility Default Service. In many states, incumbent electric utilities (now called utility distribution companies, or UDCs) provide "default" generation service to customers who choose not to switch suppliers. If a customer switches suppliers, the generation component of the default service price is subtracted from the overall UDC rate. If billing and metering services are not unbundled, marketers must therefore compete with the default generation price.

Relative to "big ticket" issues such as stranded costs, the default utility service price has received little attention, until recently, in the restructuring literature [43][44]. However, Table 1 shows that marketers regard low default service prices as perhaps the most serious barrier to development of a robust, competitive market. Given the high costs of acquiring and servicing small customers, marketers can only offer price savings if they can procure electricity at a cost sufficiently below the default price to cover their retail margin [45]. 
Marketers will be hard pressed to compete against a default service provider with a low generation price [46]. As a result, customer switching and marketer competition will be depressed and price premiums for green products can be expected to rise.

Not surprisingly, then, as shown in Table 2, all of the green marketers surveyed strongly support establishment of default service prices that provide sufficient margin to encourage entry of competitive suppliers. Interviews with marketers along with a review of regulatory filings also indicate that setting the default price is considered by marketers to be the most important regulatory decision affecting the green market. Responding to an open-ended survey question, marketers say that regulators should establish default generation prices at levels that exceed the prevailing wholesale cost of generation, therefore incorporating some of the retailing costs (e.g., administrative costs, overhead, marketing, and profit) that suppliers face when serving the retail market.

\section{Direct Access Processing and Service Fees that Erect Barriers for New Participants.} Another critical market barrier identified by marketers is direct access processing and service fees that erect barriers to new market participants. Marketers generally fear that UDCs may have an incentive to impede customer switching. As a result, marketers strongly endorse a number of rules, listed below in order of decreasing importance, to reduce entry barriers and increase customer switching (see Table 2). Most marketers believe it essential to:

- Minimize the charges for noncompetitive services imposed by UDCs on marketers, which include direct access processing fees as well as charges for other services that the UDC must provide (customer usage information requests, credit checks, etc.). In California, for example, the UDCs initially proposed direct access service fees of \$5-24 per customer, a significant cost in a low-margin business. Partly in response to the concerns of marketers, the California Public Utilities Commission decided not to allow noncompetitive service fees, at least on an interim basis.

- Allow use of load profiling for smaller customers because real-time metering is prohibitively expensive for most of those customers. Load profiling allows customers to continue to use existing electric meters. Marketers believe that requiring the purchase of real-time meters would dramatically reduce switching by smaller customers.

- Require uniformity and consistency across utility service territories for data transfer protocols, direct access service tariffs and agreements, metering and billing requirements, and other rules. Many marketers expect to compete in multiple jurisdictions and differences in rules across these jurisdictions can increase product development and marketing costs. Consequently, to the extent possible (where there are no major technical limitations), marketers believe that operational rules should be simple and uniform across service territories and perhaps even state boundaries.

- Establish parity between marketers and utilities with respect to obligations, rights, and charges for billing, metering, data transfer, service agreements, customer information and load data, avoided cost credits, etc. Because the roles and responsibilities of the UDC and the marketer are fundamentally different, full parity is neither desirable nor feasible. 
Nonetheless, marketers believe that regulators should be particularly wary of market rules proposed by utilities that erect unequal and burdensome requirements on marketers.

- Require utilities to rapidly process direct access service requests to reduce bottlenecks and ensure that customers are switched to new energy service providers as quickly as possible.

Protracted Direct Access Phase-ins that Favor Larger Customers. Some states, such as California, are proceeding rapidly toward full direct access; others, such as New York, are phasing direct access in over time. The merits of retail competition pilot programs and phaseins have been questioned by some industry observers [47], and the majority of marketers in our survey prefer a rapid transition to competition with certainty regarding the timing and scale of market access.

A large number of marketers identified protracted direct access phase-ins that favor larger customers as one of the "most serious" barriers to the green market. However, marketers' response, though positive, is not as strongly supportive as expected for two policies that address the problems of a lengthy direct-access phase-in (see Table 2). The first, a requirement that full direct access be established on a date certain without a phase-in, is not deemed "essential" by most respondents. The second, giving residential customers direct access on the same schedule as larger customers if a phase-in must exist, is also favored but not identified as essential by most marketers. A common theme expressed by many marketers in follow-up interviews was that, because of the low expected profit margin for any individual residential customer, high customer acquisition costs can easily absorb potential profit opportunities. Phase-ins and pilot programs do not generally provide a cost-efficient way to contact customers; mass media outlets are not effective for reaching only the few customers that are eligible to switch suppliers under a phase-in or pilot program. Because the primary source of revenue for green sales is expected to come from residential customers, phase-ins that favor larger commercial customers are viewed by many as particularly objectionable.

Lack of Customer Education on Retail Choice. A fundamental assumption embedded in the competitive-market model is that buyers and sellers have access to adequate and reliable information. In the competitive electricity market, most residential customers will not be accustomed to making electricity supply decisions and may not be aware of the opportunities that restructuring presents. Without effective education efforts, it is often argued, residential customers may be reluctant to exercise their choice of providers [48]. Accordingly, most U.S. states that are proceeding with restructuring have established education campaigns.

Consistent with the literature, as shown in Table 1, green marketers believe that the lack of customer education regarding retail choice is a key market barrier. Moreover, as shown in Table 2, the associated policy response, funding for broad-based, nondiscriminatory customer education on retail choice, is supported by all of the marketers. Not surprisingly, marketers that identified lack of customer education as a "most serious" market barrier tend to give higher ratings to the associated policy response in Table 2. Curiously, there appears to be some divergence on the perceived value of these programs, with clusters of marketers on both ends of the 5-point scale. Based on interviews, it appears that this difference in opinion is 
rooted in different perspectives of the relative value of publicly funded versus marketerfunded education efforts. A review of regulatory filings, for example, shows that some marketers are leery of publicly funded campaigns because of concerns that incumbent utilities will have undue influence over the messages disseminated.

Stranded Cost Recovery. Perhaps the most contentious and widely analyzed aspect of the restructuring process has been recovery of stranded costs: the above-market, sunk costs of past utility investments (see, for example, Hirst, Baxter \& Hadley [49]). Though full recovery of such costs is occurring in most U.S. states, the conventional wisdom among competitive suppliers as seen in the trade press is that $100 \%$ recovery poses a substantial barrier to entry.

Our marketer survey uncovered widely divergent and more subtle views on the effect of stranded-cost recovery. Six marketers ranked stranded-cost recovery as a "most serious" barrier, yet, as shown in Table 2, these same marketers (most of whom are unaffiliated with electric utilities) provided only modest support for a rule that would disallow recovery of some portion of these costs. Marketers that are affiliated with utilities generally oppose disallowing recovery of stranded costs. Though they go against the standard rhetoric of marketers, these responses suggest that the percentage of stranded costs recovered may not be the source of the stranded-cost market barrier or a major hindrance to the development of a competitive market. This proposition is also receiving increasing support in the academic literature [50][51]. After all, stranded costs are sunk costs and can be recovered through a non-bypassable charge imposed on all customers, whether or not they switch suppliers. This type of cost recovery should not fundamentally affect the ability of suppliers to offer savings that reflect true economic efficiency advantages: with or without stranded-cost charges, competition is primarily restricted to electricity generation and customer services.

In order to better understand the nature of the "problem" from the marketers' standpoint, an open-ended question in the survey asked marketers how they would design stranded-cost recovery mechanisms. Again, few concerns were raised about the overall level of strandedcost recovery. Instead, concern was primarily focused on designing the recovery mechanism to provide sufficient incentives for cost mitigation, to minimize entry barriers, and to not depress the default utility service price. In fact, as shown in Table 2, the majority of marketers agree in general on the design of the recovery mechanism: establish incentives for stranded cost mitigation to minimize the overall cost burden, recover costs via a stable cents/kWh charge rather than one that varies based on the market clearing price of electricity, and require these costs to be recovered rapidly.

Market Power of Electric Utilities and Their Affiliates. Market power is the ability of one firm or a set of firms to profitably maintain prices above competitive levels [52]. If incumbent electric utilities and their affiliates can exercise market power, they may be able to stifle competition and restrict the entry of other competitive suppliers to the market. Many studies have documented evidence of market power in electricity markets and have modeled the likelihood of market power under different market structures [53][54][55][56].

Given the breadth and depth of this research on and experience with market power, we expected it to be of concern to green power marketers. We were therefore somewhat 
surprised that the market-power barrier was not regarded by marketers to be as serious as those barriers discussed earlier. Nonetheless, four of the 12 marketers did rate market power as a "most serious" barrier. More interesting, however, were the results presented in Table 2. Specifically, to overcome market power concerns, most green marketers believe two frontend mitigation measures to be extremely important: the creation of an independent system operator (ISO) to control the transmission system and mandatory divestiture of utility generation assets. To a far lesser extent, some also believe that incumbent utility service providers should not be allowed a guaranteed market share by retaining the many customers who decide not to switch providers, but should instead be required to share these customers, via random assignment, auction, or some other process. Another market rule, restricting utility affiliate marketing in parent utility service territories and/or their use of the utility name and logo, received mix results; this type of rule has been offered as a way to prevent utility affiliates from using their market position to create entry barriers. Of the 10 marketers responding to this rule, four were in opposition and five found it "essential." Those in opposition are generally utility affiliates; those in support are not. So, although green power marketers are in general agreement that market power is a threat, they agree on some but not all of the possible market rules to alleviate that threat.

Insufficient Unbundling of Revenue-Cycle Services. Competition in the retail electricity market is possible in two primary arenas: (1) electricity generation and ancillary services, and (2) revenue-cycle services, including billing, metering, collections, payment processing, and customer service. In order to promote competition in the second area, services must be unbundled [57]. Because full unbundling would compensate marketers for providing revenuecycle services and expand the range of services for which competition is allowed, it could mediate the impact of a low default utility service price; that is, marketers would have another opportunity to compete against the UDC, and a retail margin would be created. Unbundling would also reinforce the relationship between the customer and the provider of each service.

One might therefore expect that insufficient unbundling of revenue-cycle services would pose a major barrier for marketers. The results presented in Table 1 suggest otherwise; only two marketers identify insufficient unbundling as one of the "most serious" market barriers. Nonetheless, as a market rule, full and fair unbundling of billing services is highly ranked by many of the survey respondents, and comments by marketers in regulatory proceedings consistently emphasize the importance of becoming a customer's primary point of contact. Because residential customers in particular are unlikely, in the near term, to benefit from sophisticated metering services, the unbundling of metering is generally supported but at a modest level. Thus, although unbundling does not appear to be perceived as a critical market barrier or high near-term priority, all marketers support expanding the range of services for which competition is allowed.

Power Pooling Structures that Do Not Allow Direct Bilateral Contracts. A fundamental debate has occurred in many jurisdictions on how to structure bulk power markets [58][59]. Some support a mandatory spot-market pool [60]; others (including most marketers) champion a "physical" bilateral trading regime, which they claim will increase marketers' flexibility [61]. 
Although many marketers have vocally opposed a pooling-based structure, surprisingly, the green marketer survey suggests that the structure of the bulk power market may be important, but is not essential to the development of the green market. As shown in Table 2, a bilateral trading structure is preferred by all respondents but was rated "essential" by just three of 11 marketers. In an additional question, six marketers stated a preference for a bilateral structure, six for a hybrid of the bilateral and pool models, and none preferred the pool-based model. Responses to an open-ended question reveal that support for the bilateral or hybrid models is based on a perception that these structures offer the greatest flexibility to marketers, and that pools will evolve naturally when and where needed. Yet just two of the green marketers surveyed felt that a pooling structure that did not allow "physical" bilateral contracts would be a "most serious" barrier to their business.

Lack of Sufficient Customer Protection Regulations. Consumer advocates often point to other restructured industries to illustrate the regulatory vigilance required to protect customers [62]. Consequently, electricity regulators are establishing customer protection regulations ranging from marketer registration, to licensing requirements, advertising guidelines, credit requirements, and customer disclosure, privacy, and disconnection obligations [63].

Despite concerns by consumer advocates, lack of customer protection regulations is considered a serious barrier by just one green marketer (see Table 1). Table 2 lists three rules that regulators could implement to enhance customer protection: marketer credit requirements, mandatory codes of conduct, and independent verification of customer orders to switch suppliers. Marketer reaction to these rules is lukewarm at best. Based on interviews with marketers and a review of regulatory filings, it appears that, while the need for minimum customer protection regulations is acknowledged, marketers are concerned that poorly designed regulations could add significantly to the cost of doing business, inhibit the development of new products and services, and reduce customer switching. Interviews also revealed a desire to limit customer protection regulations to circumstances where the possibility of marketer abuse is likely to be highest and to carefully balance tradeoffs between more stringent regulations and the establishment of barriers to market entry.

Barriers to Aggregation of Electricity Consumers Based on Geography or Affinity. Certain types of customer aggregation have the potential to increase the benefits of restructuring for smaller consumers [64]. ${ }^{2}$ Proponents of aggregation, especially when it is done by a local government, also contend that electricity supply choices made by a group of citizens collectively are more likely to reflect social and public concerns and therefore to include renewable energy, than decisions made by individual consumers [65]. One way to encourage consumer aggregation is to allow local governments to aggregate residents on an "opt-out" basis [66]. For example, Massachusetts law allows aggregation by local governments, in effect giving governments default provider status.

2 Aggregation can reduce the cost of attracting customers, increase the buying power of the aggregated group, and decrease the search costs and information barriers that a customer faces when selecting among offers. 
Interestingly, no marketer identified barriers to aggregation as a "most serious" market barrier. Moreover, as shown in Table 2, the removal of barriers to aggregation received limited support. Finally, a market rule that would allow local governments to aggregate citizens on an "opt-out" basis was opposed by seven of the 11 marketers. In some respects, these negative results are not particularly surprising. In marketer interviews, for example, we learned that local-government aggregation, especially on an opt-out basis, is frequently viewed as a potent competitor to existing retail green power marketers, who are required to attract customers individually.

\subsection{Green Power Market Facilitation Efforts}

Unlike competitive market rules, which affect all retail suppliers of electricity, green power facilitation efforts are intended to directly encourage the customer-driven market for green power and/or to broadly promote the market for renewable energy. Market facilitation efforts target the shaded "market barriers" identified in Table 1. Table 3 provides a list of prominently discussed green power facilitation efforts, divided into groups that relate to the market barriers in Table $1 .^{3}$ Green marketers in our survey were asked to rate these facilitation efforts on a five-point importance scale, with the option of stating opposition to each effort. Table 3 shows the frequency distribution of the results. As before, we asked a number of additional questions to gather details regarding specific policies. ${ }^{4}$ In discussing our results, we focus first on market barriers (and associated facilitation efforts) that were viewed as "most serious" by marketers.

3 For the purposes of this survey, we chose not to include indirect forms of facilitation efforts such as air emissions regulations, carbon taxes, etc.

4 One general finding from the table is that most facilitation efforts are opposed by at least one or two green marketers. Because the marketers are not a homogenous group, the same facilitation efforts are unlikely to be equally important to each marketer. Nonetheless, it is somewhat puzzling that facilitation efforts that would clearly positively impact the green power business are opposed. In some cases, it appears that the marketers are providing broader corporate positions rather than positions specific to their green product line. 
Table 3. Relative Ranking of Market Facilitation Efforts: Survey Results

\begin{tabular}{|l||l||l|l|l|l|r|}
\hline $\begin{array}{l}\text { Market Facilitation Efforts that } \\
\text { Differentially Affect Green Power }\end{array}$ & $\begin{array}{l}\text { My } \\
\text { company } \\
\text { opposes } \\
\text { this effort }\end{array}$ & $\begin{array}{l}\text { My company } \\
\text { believes this } \\
\text { effort is } \\
\text { "valuable" }\end{array}$ & $\begin{array}{l}\text { Marketers } \\
\text { Mal company }\end{array}$ & $\begin{array}{r}\text { My colieves this } \\
\text { effort is } \\
\text { "essential" }\end{array}$ \\
\hline
\end{tabular}

LACK OF EXISTING RENEWABLE ENERGY PLANTS THAT ARE ABLE TO SELL TO MARKETERS

Renewable energy project siting and permitting procedures that allow for more rapid construction of renewable projects

Incentives for the restructuring and buy-out of existing renewable energy qualifying facility (QF) contracts

\begin{tabular}{||l||l|l|l|l|l|}
\hline 2 & 2 & 2 & 2 & 1 & 3 \\
\hline 1 & 3 & 4 & 1 & 1 & 2 \\
\hline
\end{tabular}

LACK OF CUSTOMER EDUCATION ON RENEWABLE ENERGY

Publicly-funded education on renewable energy and green power products

\begin{tabular}{||l||l|l|l|l|l|}
\hline 1 & 4 & 1 & 0 & 4 & 2 \\
\hline
\end{tabular}

TRANSMISSION PRICING, ANCILLARY SERVICES, AND BIDDING RULES THAT PENALIZE RENEWABLE GENERATORS

Fair payment to generators that provide T\&D support benefits (e.g., local PV)

ISO/bidding rules that do not penalize intermittent generators and small generators

Ancillary service costs that do not penalize intermittent, low capacity factor generators

Transmission pricing rules that do not penalize intermittent, low capacity factor generators

Transmission pricing rules that do not penalize generators located far from load

Creation of a renewables-only power pool

\begin{tabular}{||l||l|l|l|l|l|}
\hline 0 & 3 & 2 & 2 & 5 & 0 \\
\hline 3 & 1 & 1 & 3 & 3 & 1 \\
\hline 3 & 1 & 1 & 4 & 1 & 2 \\
\hline 3 & 1 & 1 & 4 & 2 & 1 \\
\hline 3 & 2 & 2 & 2 & 1 & 1 \\
\hline 3 & 3 & 1 & 3 & 1 & 1 \\
\hline
\end{tabular}

NO MANDATORY FUEL SOURCE AND/OR EMISSIONS DISCLOSURE

Mandatory disclosure of fuel mix, emissions, and/or pricing and contract terms information

\begin{tabular}{|l||l|l|l|l|l|}
\hline 1 & 1 & 3 & 3 & 1 & 2 \\
\hline
\end{tabular}

\section{INSUFFICIENT DEFINITION(S) OF GREEN POWER}

\begin{tabular}{|c|c|c|c|c|c|c|}
\hline Third-party certification of green power products & 0 & 2 & 2 & 1 & 3 & 4 \\
\hline $\begin{array}{l}\text { Product or company endorsements by } \\
\text { environmental groups }\end{array}$ & 0 & 2 & 1 & 3 & 3 & 3 \\
\hline $\begin{array}{l}\text { State-level (PUC or legislative) definition of } \\
\text { "green" power }\end{array}$ & 3 & 2 & 2 & 2 & 2 & 1 \\
\hline $\begin{array}{l}\text { Expansion of FTC green marketing guidelines to } \\
\text { green power marketing }\end{array}$ & 2 & 2 & 4 & 2 & 2 & 0 \\
\hline \multicolumn{7}{|c|}{ OTHER GREEN POWER MARKETING FACILITATION EFFORTS } \\
\hline $\begin{array}{l}\text { Monetary production incentives or rebates to } \\
\text { customers that purchase green power }\end{array}$ & 1 & 1 & 1 & 0 & 7 & 2 \\
\hline
\end{tabular}




\begin{tabular}{|l|c|c|c|c|c|c|}
\hline $\begin{array}{l}\text { If a direct access phase-in exists, allow } \\
\text { immediate access for all customers that are } \\
\text { willing to purchase a certain percentage of } \\
\text { renewable energy }\end{array}$ & 2 & 0 & 0 & 1 & 5 & 3 \\
\hline Government purchases of green power & 2 & 1 & 1 & 2 & 6 & 0 \\
\hline $\begin{array}{l}\text { Tax or financial production incentives and/or low } \\
\text { interest loans to renewable energy generators }\end{array}$ & 1 & 2 & 1 & 2 & 2 & 3 \\
\hline $\begin{array}{l}\text { Net metering of customer-sited renewable } \\
\text { energy facilities }\end{array}$ & 1 & 3 & 1 & 3 & 2 & 1 \\
\hline $\begin{array}{l}\text { Allow customers to make renewables } \\
\text { contributions or purchases through their default } \\
\text { service provider }\end{array}$ & 5 & 3 & 0 & 1 & 2 & 1 \\
\hline $\begin{array}{l}\text { Establishment of state or federal renewables } \\
\text { portfolio standards }\end{array}$ & 6 & 1 & 0 & 2 & 0 & 2 \\
\hline
\end{tabular}

Lack of Existing Renewable Energy Plants that Are Able to Sell to Marketers. Existing renewable facilities are frequently able to sell electricity to marketers at lower cost and with more favorable terms than are new renewable plants. Consequently, in the near term at least, most green power marketers expect to use a large amount of existing generation in their product offers. In some regions, however, renewable generation is limited; even where supply is available, much of it is tied up in long-term contracts with utilities.

Table 1 shows that a lack of existing renewable plants that can sell to marketers is viewed as a critical market barrier; six of 12 respondents designate it as "most serious." Detailed results from the marketer survey, however, suggest that this barrier may not have a clear-cut regulatory remedy. One possibility would be to provide incentives for the restructuring and buy-out of existing nonutility renewable contracts--the current contract restructuring process is complex and time consuming. As shown in Table 3, this approach is looked upon somewhat favorably by most of the marketers. Not surprisingly, marketers strongly affiliated with a utility (and are, therefore, perhaps skeptical of the contract buy-out process) generally ranked this green power facilitation effort rather low, whereas nonaffiliated marketers ranked it higher. Another regulatory approach would be to speed up the process of siting and permitting new renewable facilities, thereby allowing new projects to come on-line more rapidly than is traditionally the case. This approach is also supported by the bulk of the marketers. Neither of these regulatory strategies is given the highest priority by most marketers, however. In addition, many of the marketers who rated lack of renewable supply to be a "most serious" market barrier did not rank either of these green power market facilitation efforts highly. We therefore infer that marketers may not see either facilitation effort as a clear remedy to the market barrier. In interviews, marketers noted that even with incentives for contract buy-outs and a more rapid permit and siting process, there is still likely to be a time lag between the opening of the market and the availability of generation.

Lack of Customer Education on Renewable Energy. Although they have met with varying levels of success, publicly funded education campaigns, from recycling programs to "say no to drugs" campaigns, have been and are often undertaken [67]. In addition to offering general 
education on retail choice, policymakers should also fund educational efforts specifically targeted at green power according to some renewable-energy advocates. After all, consumer research sometimes finds that consumers are poorly informed about the source of their electricity supply, are concerned about the reliability of renewables, and may not directly link their electricity use to environmental harm [68]. Some states, such as California, have already established renewable energy education programs.

The market barrier results shown in Table 1, as well as the results presented in Tables 2 and 3 , show that marketers generally believe that broader educational efforts on retail choice should be the first priority, but that programs targeted specifically at renewable energy could also be an effective use of public funds. Five marketers view lack of customer education on renewable energy as one of the "most serious" market barriers. Interestingly, though most marketers support publicly funded education campaigns on renewable energy (see Table 3), as with broader campaigns on retail choice, there is a divergence in the perceived importance of these efforts; there are clusters of marketers on both ends of the five-point scale. This result may reflect a difference of opinion among marketers on the relative value of publicly funded versus marketer funded campaigns (a similar debate exists in the academic literature-see Weiss and Tschirhart [69]-on the effectiveness of publicly funded information campaigns). The five marketers who ranked lack of customer education as a "most serious" barrier also ranked the associated green power facilitation effort highly.

Transmission Pricing, Ancillary Services, and Bidding Rules that Penalize Renewable Generators. The pricing of transmission service, the provision of ancillary services, and the rules and procedures for ISO/bidding are each the subject of significant, ongoing research. However, concerns have been raised that these operational rules could (unintentionally or deliberately) penalize some forms of renewable energy relative to more traditional generation sources [70][71]. ${ }^{5}$

The literature suggests that the combined impact of these operational "penalties" may be to dramatically increase the effective cost of renewable energy [72]. As a result, we expected that the design of these operational details would be of paramount importance to green marketers. Surprisingly, the survey results did not fulfill this expectation. Transmission pricing, ancillary services, and bidding rules that penalize renewable generators was deemed a "most critical" barrier by just three marketers. Moreover, as shown in Table 3, three marketers consistently opposed facilitation efforts that would alleviate operational penalties. These respondents appear to reflect corporate interests that go beyond the sale of green

For example, firm transmission service has historically been sold on a take-or-pay basis, meaning that generators must reserve transmission capacity in advance and pay for what is reserved regardless of how much electricity is actually transmitted. Thus, because of the intermittent nature of solar and wind power, these generators typically pay for transmission that is never used. Similar issues exist in the pricing of ancillary services. Moreover, because renewables are often located some distance from load centers, renewable generators often incur additional distance-based transmission costs. Distributed generation facilities, which can provide transmission and distribution (T\&D) support benefits, are frequently not remunerated for these services. Finally, if ISO/bidding and dispatch rules penalize generators for not being able to precisely estimate future deliveries, intermittent generators will be further disadvantaged. 
power, however, and each of these companies is strongly affiliated with larger utility parents for whom green power sales are only a small portion of business. Though the remaining nine marketers were generally supportive of policies to alleviate operational penalties, the degree of support varied widely, and few viewed such facilitation efforts as essential. Overall, these efforts are apparently viewed as somewhat less important than we expected, based on our literature review.

No Mandatory Fuel Source and/or Emissions Disclosure. Academic literature shows that private firms do not always have incentive to provide accurate, reliable, and easily comparable information on product offers [73][74]. Indeed, in the rush of businesses engaging in environmental marketing during in the late 1980s and early 1990s, concerns increased regarding the truthfulness of green claims. These issues have recently spilled over to the green power arena where many environmental claims have been criticized as misleading and/or fraudulent [75]. In part because of these concerns, governments have taken an increasingly active role in imposing disclosure and labeling requirements to enhance the quantity and quality of consumer information. For green power, mandatory disclosure and labeling of fuel mix, air emissions, and pricing is frequently argued to be vital for customer protection. Disclosure will not only benefit customers, according to its proponents, but will also help legitimate suppliers validate claims about the sources of their energy supply [76][77]. Responding to these arguments, a number of states have already implemented disclosure regulations for electricity marketing.

Despite these arguments, survey and interview responses from marketers show a positive but somewhat mixed reaction to disclosure requirements. Table 3 shows that mandatory disclosure of fuel source, emissions, and pricing is viewed positively by all but one of the green marketers. When asked separately whether some form of mandatory disclosure is critical for fostering informed customer choice, 11 out of 12 answered affirmatively and, when rating the importance of different forms of disclosure on a five-point scale, marketers chose fuel-source disclosure as most important (average rating $=4.3$ ), followed by pricing and contract terms (3.5) and air emissions (3.2). Although these results suggest that marketers are generally supportive of mandatory disclosure regulations, such regulations are clearly not perceived to be essential. A lack of fuel source and/or emissions disclosure was identified as a "most serious" market barrier by only two out of 12 marketers, and as shown in Table 3, marketers are evenly distributed in their positive rating of disclosure across the 5-point scale. The possible genesis of this positive but not overly enthusiastic reaction is discussed in Section 6.

Insufficient Definition(s) of Green Power. Though there is no single, unambiguous definition of "green" power, policymakers may want to define this term to protect customers from false and/or misleading advertising by marketers. Experience shows that some marketers make misleading claims about their products in order to attract customers. The Federal Trade Commission's (FTC) green marketing guidelines, past actions by Attorney Generals to thwart "green-washing," and a wide variety of government-run certification programs all suggest growing recognition that the government should play a role in defining green marketing terms. 
One approach to defining green power would be for the FTC to expand their green marketing guidelines to apply directly to green power marketing terms. Another approach, which is already being taken in some U.S. states, would have state PUCs, legislatures, and/or Attorney Generals define green power. Though such definitions may play an important role in customer protection, only two of the green marketers believe that lack of green power definitions are a "most serious" market barrier. Moreover, though looked upon favorably by most, neither of the two facilitation efforts discussed above ranks particularly high relative to other policies; a number of marketers oppose or give low positive rankings to these efforts. Although the two approaches are not mutually exclusive, marketers appear to more strongly support a voluntary (rather than regulatory) approach to defining green power; endorsements by environmental groups and third-party certifications of green power products are both viewed very positively by the marketers. The value of certification and endorsements has been actively debated [78][79][80][81][82]. Nonetheless, past research has found that certification efforts, if designed well, can help influence product purchases, reduce customer search costs, and spur suppliers to compete in offering environmentally preferable products [83]. Based on the apparent value of these efforts to green marketers (and customers), a number of environmental groups already endorse particular products and a green power certification effort has been launched in the U.S.[84].

Other Market Facilitation Efforts. In addition to the green power facilitation efforts described above, which specifically target the market barriers discussed earlier, a number of other policies are under review by states who want to promote the green market specifically and/or the renewable energy industry more broadly. Some of the most important programs are listed in Table 3.

Table 3 shows that the perceived value of these efforts varies among marketers. The majority of green marketers strongly favor two policies: (1) if a direct access phase-in exists, allow immediate access for all customers who are willing to purchase a certain percentage of renewable energy; and (2) offer monetary production incentives or rebates to customers who purchase green power. These two efforts are generally rated as more valuable than any of the other facilitation efforts listed. Other programs that are widely but less strongly supported include government purchases of green power, tax or financial production incentives and/or low-interest loans to renewable energy generators, and net metering of customer-sited facilities.

Two facilitation efforts are opposed by a number of the marketers. First, five of the 12 marketers object to giving customers the opportunity to make renewable contributions or purchases through their default utility service provider. Though such a policy would offer the many utility customers who choose not to switch suppliers the opportunity to support renewable energy, marketer interviews revealed a concern that this policy would create a disincentive for customers to switch suppliers and could therefore reduce competition. As a result, this policy is viewed as a competitive threat by a number of the green marketers. Second, although several of the marketers support the renewables portfolio standard (RPS), which would require all electricity suppliers to purchase a fraction of their power from renewables, six of the 11 respondents oppose this policy. The RPS, it is argued by marketers, would restrict the availability of low-cost renewables (which might all be absorbed by the 
RPS) and could make it more difficult to differentiate and sell a green product that exceeds the minimum requirements imposed by the RPS (because all electric suppliers could claim to meet the minimum renewables requirement). 


\section{Key Research Findings}

Based on the detailed results described in the previous section, it appears as if green marketers are particularly concerned that policymakers will provide incumbent utilities "undue" competitive advantages, therefore restricting the entry of and market opportunities for alternative suppliers. They also worry that regulators will make seemingly benign policydesign decisions that will, unwittingly or not, stifle development of the green market. These and other fundamental concerns are reflected in the four general research findings highlighted below.

1. Marketers Believe that Profitable Green Power Markets Will Only Develop if a Solid
Foundation of Supportive Market Rules and Facilitation Efforts Exists: In undertaking this research, we presumed that public policy decisions would play a role in shaping the green power market. Given the nature of the replies to our surveys, we conclude that green power marketers strongly agree with this premise. The large number of "essential" ratings in the marketer survey, for example, show that green marketers believe that their markets will require supportive public policies and that the existence of green marketing opportunities does not eliminate the need for policy. Marketer interviews and a review of regulatory filings bolster this contention. Moreover, although marketers hold strong convictions about which forms of policy would be most valuable (see below), they do not uniformly express a preference for a single, "optimal" approach to encouraging the green market. Instead, the survey results show that a wide variety of competitive market rules and green power facilitation efforts are believed to be important. We also observe that many marketer concerns focus not on the choice of policy mechanism but on the specific details of the mechanism. For example, marketers' fear regarding stranded costs focuses on the design of the recovery mechanism rather than the magnitude of the cost recovery.

2. Marketers Consider Establishing Price Competition and Encouraging Customer Switching as First Priorities: We find that marketers' single most pressing concern is that the competitive market rules be designed in ways that encourage overall price competition among suppliers, thereby promoting customer switching. Establishing specific green power facilitation efforts is a secondary concern. Evidence for this finding can be found in regulatory filings, interview results, and responses to the marketer survey. Of the market barriers rated as "most important" by marketers, for example, five of the top six broadly affect the competitive market and are therefore targeted with market rules (see Table 1). (Those barriers that might be targeted with facilitation efforts generally ranked as less important.) As discussed in detail earlier, setting the level of the utility default service price, which has the most direct effect on the viability of price competition, is regarded by marketers as the single most important regulatory decision. Marketer responses to other market rules, including those focusing on customer education, direct access processing and phase-ins, stranded costs, customer protection, and unbundling, also relate to encouraging price competition and customer switching. In interviews, marketers seemed particularly concerned that customer inertia and advantages held by incumbent utilities may mean that years will pass before the majority of residential consumers switch from their local utilities. An ability to offer savings to customers who switch is viewed as the best way to break down this barrier; marketers believe that their success in selling green products relates most directly to the amount of 
competition and customer switching in the market as a whole [85]. In this sense, concerns of green marketers appear rather similar to those of all marketers [86].

\section{Marketers Are Somewhat Leery of Government-Sponsored or Mandated Public} Information Programs: Some market rules may directly increase the level of "green" sales whereas other ("information-based") regulations are intended to enhance the veracity of green claims and the environmental value of green offerings. Marketers strongly support rules that increase green sales. Our research has, however, uncovered some difference of opinion over the second class of policies. On one hand, as evidenced by their generally positive response to disclosure, certification, and environmental endorsements, marketers recognize that some information requirements are needed, perhaps reflecting Porter's [87] premise that suppliers have an interest in ensuring that substandard marketing practices do not poison the entire market. On the other hand, mandatory disclosure is not uniformly hailed as an essential policy, and governmental definitions of green power are not viewed with great enthusiasm. Based on marketer interviews and a review of regulatory filings, this wariness appears to come from two sources. First, experience shows that some marketers find it worthwhile to offer inferior products and make misleading environmental claims to maximize short-term profits; these marketers may be concerned that information regulations would restrict these practices. Second, marketers appear to be deeply concerned about the down side of poorly designed and implemented information programs, which could restrict the size of the market by making green products prohibitively expensive. For example, the most critical element of disclosure, from the marketers' perspective, does not seem to be whether or not it is required but rather whether the disclosure system is designed to be practical, reasonably inexpensive, and free of administrative burdens that might unintentionally interfere with green market operations [88]. ${ }^{6}$

\section{Marketers Often Oppose Three Specific Renewable Energy Policies that May Have} Negative Impacts on their Profitability: Public policies can facilitate, augment, or replace certain types of private exchange [89]. The majority of policies considered in this paper facilitate voluntary transactions between green marketers and customers. Some policies covered, however, support renewable generation more directly and therefore only affect the existing green market in a secondary fashion. Although marketer response to policies that facilitate marketer-customer transactions is often resoundingly positive, survey responses show a more negative reaction to some policies that do not specifically target the development of green markets. Evidence presented earlier shows that most of the marketers support certain policies directed at renewable generators, such as tax incentives, financial support, and net metering. At least three policies, however, are opposed by a number of marketers: (1) allowing local governments to act as default service providers (7 of 12 marketers oppose this policy), (2) enabling customers to make renewable contributions

Another example comes from the response to green power definitions; private and nonprofit efforts were favored over governmental ones. The primary reason stated by the marketers' for their unenthusiastic reaction to governmental definitions is the potential down side if the definitions "overly restrict" the types of resources and products that can be classified as green, thereby limiting innovation in product design and reducing the availability of green resources. For example, if green definitions proceed on a state-by-state basis, regional disparities could force marketers to design and market products state by state rather than using a regional strategy. 
through their default providers (5 of 12 oppose), and (3) creating renewables portfolio standards (6 of 11 oppose). Why are some policies that support renewable generation perceived as valuable by the vast majority of marketers while others are not? Marketer interviews suggest that the root cause is a fear about the inadvertent but potentially negative impacts of certain renewable policies on the size of the green market and on the marketers' profitability. While many forms of renewable energy policy are believed to be consistent with and indirectly supportive of the green market, in these three instances marketers fear that the enactment of the policy may reduce customer demand for their green power products. Marketers therefore believe that policymakers need to carefully weigh the intended benefits of these policies with their possibly negative consequences. In general, and not surprisingly, marketers are more strongly supportive of policies that are compatible with the existing set of market institutions and that facilitate transactions between willing buyers and sellers of green power. 


\section{Implications, Tensions, and Unanswered Questions}

What implications can be drawn from our findings for those interested in supporting the green market in order to capture the environmental benefits of renewables? We have thus far avoided drawing these broad normative conclusions. After all, this research prioritizes policy instruments from the perspective of just one stakeholder group. Policymakers, though, must make complex tradeoffs among numerous stakeholder interests and social objectives. Therefore, we do not attempt to identify an "ideal" suite of rules and facilitation efforts here. Nonetheless, we do believe that marketers' views can shed light onto how best to foster renewable energy via the green market and how best to target incremental research activities. Our research has also helped uncover several tensions among marketers' interests and the presumed interests of other stakeholders (as expressed in regulatory filings and advocacy efforts). An understanding of the disparity of interests can help advocates and policymakers as they consider programs to support renewable energy and the green market.

First we highlight three broad implications of our work for policy and research. Although they are not proven, these implications appear relatively uncontroversial:

- $\quad$ First, responses of marketers suggest that the design of market rules and facilitation efforts will not only affect but will play an absolutely critical role in shaping the size of the green market and the environmental quality of the products it offers. Thus, for those interested in seeing the green market stimulate development of renewables, and for those interested in researching green markets more generally, significant consideration will need to be given to both traditional and new forms of policy. There seems to be no escaping the role of policy in the development of renewable markets. Importantly, this implication runs counter to many modern debates (described in Section 2.2) that separate "policy" and "market" approaches to commercializing renewables and that de-emphasize the importance of policy for the green market itself.

- Second, it does not appear that there is a single, "optimal" approach to encouraging the green market; neither marketers nor other stakeholders have identified such a strategy. Moreover, many concerns expressed by marketers emphasize detailed implementation issues that arise during restructuring proceedings, not broader policy considerations. Just as all markets are exceedingly varied and complex, apparently so are the instruments that might be used to frame or modify those markets. A heightened awareness of the impacts of seemingly innocuous market design decisions therefore seems called for, and a wide array of rules and facilitation efforts may need to be considered by policymakers and green power advocates alike.

- $\quad$ Third, perhaps the most important implication of this study is its suggestion that green power proponents and researchers may want to place additional emphasis on laying the basic foundation for retail (rather than wholesale) competition. The emphasis on retail market design differs from what has been emphasized in academic discussions of restructuring: wholesale market design and stranded costs. It also differs from the emphasis thus far in discussions of green power: green power facilitation efforts, but not competitive market rules. Our findings indicate that policymakers and advocates 
should consider expanding their renewables-policy toolkit to include the detailed market rules that affect retail competition. Rules that encourage overall price competition and customer switching, particularly default utility service prices, appear to deserve special attention. Such rules directly address marketers' fears about the advantages held by incumbent utilities and the barriers to entering the market.

These new insights into the green power market are likely to be uncontroversial. But, if policymakers follow the marketers' guidance on the design of specific policies, will renewable energy use increase and will this increase come without sacrificing the interests of other important stakeholders (e.g., consumers, utilities, environmental advocates)?

As noted earlier, many of the marketers' detailed preferences are based on two fundamental concerns: (1) the impact of advantages held by incumbent utilities on retail competition and customer switching, and (2) the negative, unintentional effects of seemingly benign market design decisions. These fundamental concerns are likely to be shared by the majority of stakeholders interested in electric industry reform. Thus, in many instances the detailed preferences of marketers are likely to serve the interests of other stakeholders and thus form a strong basis for policy decisions. For example, setting the default generation price to reflect a retail margin, educating customers about choice, reducing direct assess barriers, ameliorating market power, and unbundling are all rules that most stakeholders (with the possible exception of utilities) would agree with on principle. In fact, as argued by Michelman [90], the design of these rules is fundamental to the development of overall retail competition. Many of these rules also appear consistent with the goal of stimulating renewable energy development. For example, marketers believe that rules that stimulate price competition and encourage overall switching will maximize the number of green power customers. Wiser et al. [91] show that this contention is strongly supported by empirical evidence in four U.S. states, where variation in the number of switches to green power is linked to default utility generation prices (and therefore to overall switching activity). Accordingly, if policymakers respond to green marketers' concerns regarding these market rules, it seems likely that green product sales will increase.

In undertaking the research for this study, however, we have identified three key questions that address areas where marketers' preferences may not increase renewable energy development and/or serve the needs of all stakeholders. In these instances, the appropriate policy response is uncertain. Because the focus of this study has primarily been on marketers and because green markets continue to evolve, full answers to these questions are not yet available. Nonetheless, these questions are at the heart of most current debates related to green markets and highlight important tensions between the interests of marketers and those presumed to be held by other stakeholders.

\section{To what extent should price competition and customer switching be encouraged at the} expense of cost shifting? At a certain point, marketers' the preferences for increased price competition and customer switching begin to diverge from the interests of other stakeholder groups. Marketers clearly have an interest in promoting rules that provide not just parity with incumbent utilities but competitive advantage. Take the example of the default utility generation price, the most important rule identified by marketers. Though there is increasing 
agreement among a wide variety of interest groups that the default price should incorporate some form of retail margin [92][93], there is little consensus on the appropriate magnitude of that margin [94]. A high retail margin is typically supported by marketers because it promotes price competition, breaks down customer inertia, and encourages near-term competitive entry. Yet, a high margin is generally opposed by utilities and their remaining customers because it entails cost shifting and would reduce the utility's customer base. We have not yet heard a persuasive case for any particular standard of "fair" or even "efficient" competition in these situations. More research is therefore required in this area and policymakers must delicately balance a desire to enhance retail price competition (and in so doing increase green power sales) with a need to minimize cost shifting.

2. What requirements should be imposed to ensure credibility in the green products and marketing? Marketers' preferences for certain information regulations may also diverge from those of society. Marketers have a strong desire to expand green power sales. Presumably, though, the broader social interest associated with the green market is in increasing renewable energy supply and thereby creating net environmental improvements. Increased green sales will only deliver on this promise if green products are truly green and contain incremental renewables supply. Marketers, however, remain leery of information requirements, especially state- or FTC-derived green power definitions. This wariness may be justified from a societal standpoint when the information requirements are so restrictive that they "unduly" limit green power sales and therefore renewable energy supply. On the other hand, too much leniency may allow marketers to maximize sales of substandard products that do little to increase renewable energy supply, a serious concern of most environmental and consumer groups [95]. Unfortunately, as noted by Beales, Craswell \& Salop [96], satisfactory principles for determining when and how government ought to respond to consumer information problems have not yet been developed. Consequently, while this study illustrates the need to consider the impact of information requirements on product innovation, product design, and green power sales, the appropriate scope of information regulations remains unclear.

3. How should the green power market relate to broader renewable policies? A final question facing policymakers is how best to target policy efforts: toward fostering a customer-driven green market or toward renewable generators themselves. Marketers generally support policy tools that foster the green power market directly. Understandably, they are particularly concerned about renewable policies that they believe might negatively impact their profitability. Interviews with other stakeholders make clear, however, that at least some renewable energy, consumer, and environmental representatives doubt whether the green market can successfully support significant quantities of incremental renewable energy [97][98]. A focus on policies to foster the green market, they claim, may be inefficient and may divert attention from more important policies targeted directly at renewable generators. It seems evident therefore that, wherever possible, renewable policies should be designed to at least not limit marketers' opportunities to offer high-quality green power products. At the same time, enthusiasm for green marketing may need to be attenuated by a realistic understanding of its limits, and policy choices will not always be reducible to making existing green markets work better. The interaction between green marketing and general renewable policies clearly remains a fertile area for further research and policy consideration. 


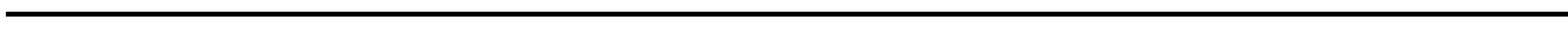




\section{Concluding Thoughts}

It is too early to empirically estimate the likely size of the green market, or to predict the ability of that market to deliver sizable environmental benefits [99]. As others have shown, consumer markets for green power cannot be expected to fully satisfy broader environmental objectives [100]. Nonetheless, experience in both regulated and deregulated contexts provides empirical evidence that a niche market for "green power" may exist among electric customers.

This study challenges the position, sometimes asserted in debates on green consumerism, that profitable, sizable, credible markets for green power products will evolve naturally without supportive public policies. We have shown that marketers of green power identify as vital a range of competitive market rules and green power market facilitation efforts. Many green marketer preferences are consistent with those presumed to be held by other stakeholders as well. We therefore conclude that even voluntary green product markets are likely to require a foundation of supportive policies.

Though the regulatory and legislative "rules of the game" are vitally important in orchestrating the scope and nature of competition, Williamson [101] notes that only rarely do windows of opportunity open in which broad reform of these rules is possible. It is apparent that restructuring provides one of those windows in which broad reform is possible. If policymakers are to design the rules-of-the-game in ways that enable and encourage the increased use of renewable energy via green power markets, there is not likely to be a better time than the present.

Academic theory offers some insight into how to select and design policy instruments for the green market, but there are limits to the use of existing theory for policy prescription. In this study, we have primarily used direct surveys and interviews of marketers to uncover policy and research insights. From the marketers' perspective, we have documented significant differences in the relative importance of policy instruments and have identified specific policy details that could impede the development of the green market. It is hoped that our findings will add to understanding of policy-market interactions and contribute to the development of sound policy toward green markets.

Designing the rules that will govern the electricity market is a complex task, however, requiring tradeoffs among competing and sometimes conflicting goals. Much remains to be done to develop systematic methods for selecting policies. We have therefore identified areas where the interests of marketers and those of society might diverge, posing three questions to direct future research. Beyond cautioning that the devil truly is in the details, we hope that the work presented in the preceding pages provides a framework for policymakers to begin targeting their efforts and offers a fertile starting point for subsequent research efforts. 


\section{References}

1. Nader, N., and R. Norgaard (1996). "Efficiency and Sustainability in a Restructured Electricity Market: The Renewables Portfolio Standard." The Electricity Journal 9 (6): 37-49.

2. Joskow, P. (1998). “Electricity Sectors in Transition.” The Energy Journal 19 (2): 25-52.

3. Nakarado, G. (1996). "A Marketing Orientation is the Key to a Sustainable Energy Future." Energy Policy 24 (2): 187-193.

4. Holt, E. and R. Wiser (1998). Understanding Consumer Demand for Green Power. Prepared for the National Wind Coordinating Committee.

5. Wiser, R., J. Fang, K. Porter and A. Houston (1999). Green Power Marketing in Retail Competition: An Early Assessment. NREL Issues Brief. Golden, Co.: National Renewable Energy Laboratory.

6. Fouquet, R. (1998). "The United Kingdom Demand for Renewable Energy in a Liberalized Market." Energy Policy 26 (4): 281-293.

7. Farhar, B., and A. Houston (1996). "Willingness to Pay for Electricity from Renewable Energy." Proceedings: 1996 ACEEE Summer Study on Energy Efficiency in Buildings. Pacific Grove, Calif.: American Council for an Energy-Efficient Economy.

8. Costello, K. and R. Graniere (1997). "The Outlook for a Restructured U.S. Electric Power Industry: Lessons from Deregulation.” The Electricity Journal 10 (4): 81-91.

9. Wiser, R., J. Fang, K. Porter and A. Houston (1999). Green Power Marketing in Retail Competition: An Early Assessment. NREL Issues Brief. Golden, Co.: National Renewable Energy Laboratory.

10. Knight, J. (1998). "Reforming California: Reflections on the Morning After." Public Utilities Fortnightly, December, 50-53.

11. Swedberg, R. (1994). "Markets as Social Structures." Chapter 11 in N. Smelser and R. Swedberg (eds.) The Handbook of Economic Sociology. Princeton University Press: Princeton, New Jersey.

12. Abolafia, M. and N. Biggart (1991). "Competition and Markets: An Institutional Perspective." Chapter 13 in A. Etzioni and P. Lawrence (eds) Socio-Economics: Toward a New Synthesis. Armonk, NY: M.E. Sharpe, Inc.

13. Harris, R. and J. Carman (1983). "Public Regulation of Marketing Activity: Part I: Institutional Typologies of Market Failure." Journal of Macromarketing, Spring, 49-58.

14. Furubotn, E., and R. Richer (1991). "The New Institutional Economics: An Assessment.” In F. Furubotn and R. Richer (eds). The New Institutional Economics. College Station, Tex.: Texas A\&M Press.

15. North, D. (1991). “Institutions.”Journal of Economic Perspectives 5: 97-112.

16. Granovetter, M. (1985). "Economic Action and Social Structure: The Problem of Embeddedness." American Journal of Sociology 91: 481-501.

17. Abolafia, M. and N. Biggart (1991). "Competition and Markets: An Institutional Perspective." Chapter 13 in A. Etzioni and P. Lawrence (eds) Socio-Economics: Toward a New Synthesis. Armonk, NY: M.E. Sharpe, Inc. 
18. Williamson, O. (1996). The Mechanisms of Governance. New York: Oxford University Press.

19. Norgaard, R. (1995). "Intergenerational Commons, Globalization, Economism, and Unsustainable Development." Advances in Human Ecology 4: 141-171.

20. Porter, K. (1996). Open Access Transmission and Renewable Energy Technologies. Topical Issues Brief. NREL/SP-460-21427. Golden, Co.: National Renewable Energy Laboratory.

21. Harris, R. and J. Carman (1983). "Public Regulation of Marketing Activity: Part I: Institutional Typologies of Failure.” Journal of Macromarketing, Spring, 49-58.

22. Bator, F. (1958). “The Anatomy of Market Failure.” Quarterly Journal of Economics 72 (3), 351-379.

23. Samuelson, P. (1947). Foundations of Economic Analysis. Cambridge, Mass.: Harvard University Press.

24. Stiglitz, J. (1989). The Economic Role of the State. Oxford, U.K.: Basil Blackwell.

25. Harris, R. and J. Carman (1984). "Public Regulation of Marketing Activity: Part II: Regulatory Responses to Market Failure." Journal of Macromarketing, Spring, 41-52.

26. Nelson, R. and S. Winter (1982). An Evolutionary Theory of Economic Change. Cambridge, Mass.: Harvard University Press.

27. Friedman, L. (1981). "Public Institutional Structure and Resource Allocation: The Analysis of Adjustment." Research in Public Policy Analysis and Management 2: 303-325.

28. Bowles, S. (1991). "What Markets Can--and Cannot--Do.” Challenge, July-August, 11-16.

29. Ostrom, E. (1998). "A Behavioral Approach to the Rational-Choice Theory of Collective Action." American Political Science Review.

30. Wiser, R. (1998). "Green Power Marketing: Increasing Customer Demand for Renewable Energy." Utilities Policy 7 (2):107-119.

31. Ostrom, E. (1998). "A Behavioral Approach to the Rational-Choice Theory of Collective Action." American Political Science Review.

32. Arrow K. (1969). "The Organization of Economic Activity: Issues Pertinent to the Choice of Market Versus Non-Market Allocation." The Analysis and Evaluation of Public Expenditure: The PPB System, Vol. 1. U.S. Joint Economic Committee, $91^{\text {st }}$ Congress, $1^{\text {st }}$ Session. Washington, D.C.: U.S. Government Printing Office, 59-73.

33. Friedman, L. (1981). "Public Institutional Structure and Resource Allocation: The Analysis of Adjustment." Research in Public Policy Analysis and Management 2: 303-325.

34. Coase, R. (1992). “The Institutional Structure of Production.” American Economic Review 82: 713-719.

35. Williamson, O. (1996). The Mechanisms of Governance. New York: Oxford University Press.

36. Coase, R. (1960). "The Problem of Social Cost.” Journal of Law and Economics 2: 1-40.

37. Hahn, R. and R. Stavins (1992). "Economic Incentives for Environmental Protection: Integrating Theory and Practice." AEA Paper and Proceedings 82 (2): 464-468. 
38. Friedman, L. (1981). "Public Institutional Structure and Resource Allocation: The Analysis of Adjustment." Research in Public Policy Analysis and Management 2: 303-325.

39. Fouquet, R. (1998). "The United Kingdom Demand for Renewable Energy in a Liberalized Market." Energy Policy 26 (4): 281-293.

40. Nogee, A., S. Clemmer, B. Paulos and B. Haddad. (1999). "Powerful Solutions: 7 Ways to Switch America to Renewable Electricity." Cambridge, Mass.: Union of Concerned Scientists.

41. Karakaya, F. and M. Stahl (1991). Entry Barriers and Market Entry Decisions: A Guide for Marketing Executives. New York, NY: Quorum Books.

42. Etzioni, A. (1988). The Moral Dimension: Toward a New Economics. New York: The Free Press.

43. Rohrbach, J. (1999). "Made in the Keystone State: Pennsylvania's Approach to Retail Electric Competition." The Electricity Journal 12 (1): 26-39.

44. Nogee, A., S. Clemmer, B. Paulos and B. Haddad. (1999). "Powerful Solutions: 7 Ways to Switch America to Renewable Electricity." Cambridge, Mass.: Union of Concerned Scientists.

45.Talbot, N. (1999). “The Right Path for Electricity Restructuring: 10 Guidelines for State Legislation.” The Electricity Journal 12 (1): 16-25.

46. Regulatory Assistance Project. (1999) "Setting Rates for Default Service: The Basics." Issue Letter. January.

47. Landon, J., and E. Kahn (1996). "Retail Access Pilot Programs: Where's the Beef?" The Electricity Journal 9 (10): 19-25.

48. Costello, K. and R. Graniere (1997). "The Outlook for a Restructured U.S. Electric Power Industry: Lessons from Deregulation.” The Electricity Journal 10 (4): 81-91.

49. Hirst, E., L. Baxter and S. Hadley (1997). "Transition Cost Issues for US Electricity Utilities.” Annual Review of Energy and the Environment 22: 119-154.

50. Joskow, P. (1996). "Does Stranded Cost Recovery Distort Competition." The Electricity Journal 9 (3): $31-45$.

51. Tye, B. and F. Graves (1996). "Stranded Cost Recovery and Competition on Equal Terms." The Electricity Journal 9 (10): 61-70.

52. Costello, K. and K. Rose (1998). "Some Fundamental Questions on Market Power: No Easy Answers for State Utility Regulators.” The Electricity Journal 11 (6): 71-79.

53. Wolak, F. (1998). "Market Design and Price Behavior in Restructured Electricity Markets: An International Comparison." Proceedings: 1998 POWER Electricity Industry Restructuring: A Research Conference. Berkeley, Calif.: Program on Workable Energy Regulation.

54. Rudkevich, A., M. Duckworth and R. Rosen (1998). "Modeling Electricity Pricing in a Deregulated Generation Industry: The Potential for Oligopoly Pricing in Poolco." The Energy Journal 19 (3): 1949.

55. Newbery, D. (1995). “Power Markets and Market Power.” The Energy Journal 16 (3): 39-66. 
56. Borenstein, S., J. Bushnell, E. Kahn and S. Stoft (1995). "Market Power in California Electricity Markets." Utilities Policy 5 (3/4): 219-236.

57. Costello, K. (1995). "The Next Gordian Knot for State Regulators and Electric Utilities: The Unbundling of Retail Services." The Electricity Journal 8 (9): 38-49.

58. Kahn, E. and S. Stoft (1995). Organization of Bulk Power Markets: A Concept Paper. LBNL-37508. Berkeley, Calif.: Lawrence Berkeley National Laboratory.

59. Hartman, R. and R. Tabors (1998). "Optimal Operating Arrangements in the Restructured World: Economic Issues.” Energy Policy 26 (2): 75-83.

60. Garber, D., W. Hogan and L. Ruff (1994). "An Efficient Electricity Market: Using a Pool to Support Real Competition.” The Electricity Journal 7 (7): 48-60.

61. Levin, R. (1995). "Centralized Pools: Description, Critique, and Recommendations: A Contribution to the Dialogue. New York Mercantile Exchange.

62. Stutz, J., B. Biewald, D. Singh, T. Woolf, G. Edgar and W. DeForrest (1996). Can We Get There from Here? The Challenges of Restructuring the Electricity Industry so that We Can All Benefit. A White Paper prepared by Tellus Institute and Wisconsin Energy Conservation Corp.

63. Alexander, B. (1998). "Comparison of Customer Protection Provisions in State Legislation on Retail Electric Competition.” March.

64. Stutz, J., B. Biewald, D. Singh, T. Woolf, G. Edgar and W. DeForrest (1996). Can We Get There from Here? The Challenges of Restructuring the Electricity Industry so that We Can All Benefit. A White Paper prepared by Tellus Institute and Wisconsin Energy Conservation Corp.

65. Asmus, P. (1997). "Power to the People: Local Governments Go Green.” The Electricity Journal 10 (9), 78-82.

66. Ridley, S. (1997). "Local Government: The Sleeping Giant in Electric Industry restructuring." The Electricity Journal 10 (9): 13-21.

67. Weiss, J., and M. Tschirhart (1994). "Public Information Campaigns as Policy Instruments." Journal of Policy Analysis and Management 13 (1): 82-119.

68. Moskovitz, D., R. Cowart, A. Levy and B. Roe (1998). "What Consumers Need to Know if Competition is Going to Work." The Electricity Journal 11 (5):38-48.

69. Weiss, J., and M. Tschirhart (1994). "Public Information Campaigns as Policy Instruments." Journal of Policy Analysis and Management 13 (1): 82-119.

70. Ellison, C., A. Brown and N. Rader (1998). Wind Energy System Operation and transmission Issues Related to Restructuring. Prepared for the National Wind Coordinating Committee.

71.Stoft, S., C. Webber and R. Wiser (1997). Transmission Pricing and Renewables:Issues, Options, and Recommendations. LBNL-39845. Berkeley, Calif.: Lawrence Berkeley National Laboratory.

72. Ellison, C., A. Brown and N. Rader (1998). Wind Energy System Operation and Transmission Issues Related to Restructuring. Prepared for the National Wind Coordinating Committee.

73. Akerlof, G. (1970). “The Market for 'Lemons': Quality Uncertainty and the Market Mechanism.” Quarterly Journal of Economics 84: 488-500. 
74. Beales, H., R. Craswell and S. Salop (1981). "The Efficient Regulation of Consumer Information." Journal of Law and Economics 24: 491-539.

75. Rader, N. (1998). “Green Buyers Beware.” Public Citizen. Washington, D.C.

76. Holt, E. (1997). Disclosure and Certification: Truth and Labeling for Electric Power. Issue Brief \#5. College Park, Md.: Renewable Energy Policy Project.

77.Moskovitz, D., T. Austin, C. Harrington, B. Biewald, D. White, and R. Bigelow (1997). Full Environmental Disclosure for Electricity: Tracking and Reporting Key Information. The National Council on Competition and the Electric Industry.

78. Abt Associates (1994). Determinants of Effectiveness for Environmental Certification and Labeling Programs. EPA 742-R-94-001. Washington, D.C.: Environmental Protection Agency.

79. Taylor, D. (1958). “Certification Marks--Success or Failure?” The Journal of Marketing 23 (1): 39-47.

80. Parkinson, T. (1975). "The Role of Seals and Certification of Approval in Consumer Decision-Making." The Journal of Consumer Affairs 9 (1): 1-15.

81. Laric, M. and D. Sarel (1981). "Consumer (Mis)Perceptions and Usage of Third Party Certification Marks, 1972 and 1980: Did Public Policy Have an Impact.” Journal of Marketing 45: 135-142.

82. Phelps, D. (1949). "Certification Marks Under the Lantham Act.” The Journal of Marketing 13 (4): 498505.

83. Abt Associates (1993). Status Report on the Use of Environmental Labels Worldwide. EPA 742-R-9-93001. Washington, D.C.: Environmental Protection Agency.

84. Rabago, K., R. Wiser, and J. Hamrin (1998). “The Green-e Program: An Opportunity for Customers.” The Electricity Journal 11 (1): 37-45.

85. Counihan, R. (1999).”Energy Issues for 1999: Post Transition Market Structure.” Testimony on behalf of Green Mountain Energy Resources before the Caliofornia State Senate. 9 February.

86. Electric Power Supply Association. (1999). "Retail Electric Competition: Getting it Right!” EPSA White Paper. January.

87. Porter, M. (1980). Competitive Strategy: Techniques for Analyzing Industries and Competitors. New York, NY: The Free Press.

88. Renewable Energy Alliance (1998). "Disclosure: A Vital Tool for Consumers." A Policy Paper on Electricity Source Disclosure from the Renewable Energy Alliance. October.

89. Harris, R. and J. Carman (1984). "Public Regulation of Marketing Activity: Part II: Regulatory Responses to Market Failure." Journal of Macromarketing, Spring, 41-52.

90. Michelman, T. (1998). "Flops to Tops: Factors Affecting Robust Energy Markets." Xenergy Consulting.

91. Wiser, R., J. Fang, K. Porter and A. Houston (1999). Green Power Marketing in Retail Competition: An Early Assessment. NREL Issues Brief. Draft. Golden, Co.: National Renewable Energy Laboratory.

92. Knight, J. (1998). "Reforming California: Reflections on the Morning After." Public Utilities Fortnightly, December, 50-53. 
93.Nogee, A., S. Clemmer, B. Paulos and B. Haddad. (1999). "Powerful Solutions: 7 Ways to Switch America to Renewable Electricity." Cambridge, Mass.: Union of Concerned Scientists.

94. Kahn, A. (1998). "Electric Deregulation: Defining and Ensuring Fair Competition." The Electricity Journal 11 (4): 39-49.

95. Wiser, R., J. Fang, K. Porter and A. Houston (1999). Green Power Marketing in Retail Competition: An Early Assessment. NREL Issues Brief. Draft. Golden, CO: National Renewable Energy Laboratory.

96. Beales, H., R. Craswell and S. Salop (1981). "The Efficient Regulation of Consumer Information." Journal of Law and Economics 24: 491-539.

97. Rader, N., and B. Short (1998). "Competitive Retails Markets: Tenuous Ground for Renewable Energy." The Electricity Journal 11 (3): 72-80.

98. Energy Center of Wisconsin (1997). Green Power in Perspective: Lessons from the Marketing of Consumer Goods. Madison, WI: Energy Center of Wisconsin.

99. Wiser, R., J. Fang, K. Porter and A. Houston (1999). Green Power Marketing in Retail Competition: An Early Assessment. NREL Issues Brief. Draft. Golden, Co.: National Renewable Energy Laboratory.

100. Rader, N., and R. Norgaard (1996). "Efficiency and Sustainability in a Restructured Electricity Market: The Renewables Portfolio Standard." The Electricity Journal 9 (6): 37-49.

101. Williamson, O. (1998). "Transaction Cost Economics: How it Works; Where it is Headed." De Economist 146: 23-58. 